\title{
PERBANDINGAN PERILAKU BANGUNAN BERTINGKAT MENENGAH DENGAN MATERIAL CROSS-LAMINATED TIMBER (CLT) BERDASARKAN SNI 1726:2012 DAN SNI 1726:2019
}

\author{
Ika Rahmawati Suyanto
}

Sekolah Vokasi Universitas Gadjah Mada

Email: ika.rahmawati.s@mail.ugm.ac.id

\begin{abstract}
ABSTRAK
Pembangunan yang berkelanjutan dengan konsep bangunan hijau membuat cross-laminated timber (CLT) saat ini menjadi alternatif yang dipertimbangkan dalam pembangunan di area urban. Berbeda dari glulam, lapisanlapisan kayu pada CLT saling tegak lurus sehingga memberikan tahanan geser yang lebih besar pada dua arah transversalnya. Sementara itu, peraturan bangunan tahan gempa di Indonesia mengami perubahan dari SNI 1726:2012 menuju SNI 1726:2019 dengan perubahan nilai parameter respon spektra yang cukup berbeda. Konsekuensi akibat perubahan peraturan ini dianalisa terhadap perubahan perilaku struktur CLT. Dari hasil analisa didapatkan bahwa gaya lateral diafragma dan simpangan terbesar berdasarkan SNI 1726:2012 adalah sebesar $1433 \mathrm{kN}$ dan $42 \mathrm{~mm}$. Sedangkan gaya geser dan simpangan terbesar berdasarkan SNI 1726:2019 adalah sebesar $842 \mathrm{kN}$ dan $24,5 \mathrm{~mm}$. Dari hasil tersebut dapat dikatakan bahwa CLT masih efektif digunakan sebagai material untuk bangunan bertingkat menengah.
\end{abstract}

Kata kunci: bangunan tahan gempa, cross-laminated timber, dinding geser kayu

\begin{abstract}
Greed building is one of the main concepts in our soiety as we heading towards sustainable development goals. Cross-laminated timber (CLT) becomes popular as an alternative in constructing a building in urban area. Unlike glulam, each layer of CLT is stacked perpendicularly of, providing CLT with extra shear capacity in all transverse direction. Meanwhile, the standard of seismic resistant building in Indonesia has been updated from previously SNI 1726:2012 to the latest SNI 1726:2019, along with the change of respon spectrum parameter maps. The behaviour of CLT structure is therefore studied as the consequences of this change in order to see whether the performance of CLT structure still statisfy the lastest standard. The result shows that the shear load and maximum drift in accordance to SNI 1726:2012 are about $1433 \mathrm{kN}$ and $42 \mathrm{~mm}$, respectively. The shear load and maximum drift in accordance too SNI 1726:2019 are $842 \mathrm{kN}$ and 24,5 mm, respectively. Both result shows that CLT mid-rise structure statisfy the previous standard and latest standard.
\end{abstract}

Keywords: seismic-resistant building, cross-laminated timber, wooden shear wall

\section{PENDAHULUAN}

Peningkatan populasi manusia dari tahun ke tahun dan keterbatasan lahan membuat tingkat kepadatan penduduk pada suatu kawasan meningkat. Kawasan dengan kepadatan penduduk yang tinggi dikenal dengan istilah daerah urban. Pada tahun 2018, sebanyak 55\% penduduk di dunia tinggal di kawasan yang tergolong ke dalam daerah urban dan diperkirakan akan terus meningkat hingga $68 \%$ pada tahun 2050 (UN, 2018). Untuk memfasilitasi kebutuhan manusia berupa tempat tinggal dan tempat beraktivitas pada daerah urban, maka pembangunan gedung-gedung bertingkat menjadi umum dijumpai. Secara tidak langsung, peningkatan kepadatan ini 
Perbandingan Perilaku Bangunan... (lka/ hal 130-143)

berdampak pada tingginya tingkat konstruksi. Salah satu imbas akibat tingginya tingkat konstruksi adalah kenaikan limbah konstruksi yang dihasilkan selama proses pelaksaan konstruksi atau limbah dari bangunan lama yang dihancurkan.

Sementara itu United Nation, 2015, mengeluarkan gagasan bersama berupa cita-cita pengembangan berkelanjutan atau dikenal dengan sustainable development goals (SDGs). Salah satu tujuan dari SDGs adalah untuk mengurangi emisi dan membangun daerah urban yang berkelanjutan. Beton diketahui menyumbangkan emisi $\mathrm{CO}_{2}$ sebesar $6 \%$ dari total emisi dunia (Hermawan et al, 2015). Menanggapi hal tersebut gagasan untuk menggunakan bahan konstruksi yang lebih ramah lingkungan mendorong kayu untuk kembali dipertimbangkan sebagai material utama bangunan.

Penggunaan kayu sebagai bahan bangunan sudah berlangsung sejak dahulu kala (Shi et al, 2020), hanya saja terbatas pada bangunan satu hingga dua lantai. Kayu memiliki sifat yang ringan dan mudah didapatkan, khususnya di Indonesia, dan merupakan sumber yang dapat diperbaharui. Namun, kayu juga memiliki kelemahan, yaitu mudah terbakar, lapuk, dan kekuatannya (terutama terhadap geser) hanya kuat pada sumbu yang searah dengan arah seratnya.

Dalam perkembangannya, muncul berbagai teknologi untuk meningkatkan kualitas produk kayu. Salah satunya adalah crosslaminated timber (CLT). CLT adalah kayu laminasi yang memiliki arah serat kayu yang berlawanan antar lapisannya. Hal ini membuat CLT memiliki tahanan pada dua arahnya. Tidak hanya itu, akibat proses laminasi dengan tekanan yang tinggi, maka pori-pori kayu pada CLT hampir hilang. Dengan begitu, daya tahan CLT terhadap air menjadi meningkat (Brandner et al, 2016). Dalam perkembangannya, CLT juga telah diteliti daya tahannya terhadap kebakaran. Hasil riset dari Fire Protection Research Foundation, 2010, menyatakan bahwa CLT mampu bertahan selama 24 jam dalam kobaran api. Dengan inovasi yang terus dilakukan terhadap material ini, kini CLT telah digunakan dalam berbagai bangunan bertingkat menengah di beberapa negara.

Pada 2015 misalnya, gedung tertinggi yang dibangun dengan material utama CLT adalah gedung apartemen di Bergen Norway dengan 18 lantai dan tinggi $49 \mathrm{~m}$. Hal ini menjadi bukti bahwa CLT memiliki potensi yang besar untuk digunakan sebagai bahan bangunan pada daerah urban. Namun, di Indonesia sendiri penggunaan dan produksi CLT belum menjadi sorotan. Keandalan bangunan yang terbuat dari CLT perlu dikaji lebih dalam sebelum diterapkan di lapangan. Kajian terhadap keandalan ini juga didasarkan pada peraturan terkait bangunan gedung yang berlaku di Indonesia. Selain itu, sebagai negara yang yang sebagian besar daerah urbannya berada di daerah rawan gempa, maka beban gempa menjadi salah satu isu yang harus dikaji pada prospek bangunan CLT.

Di samping itu, peraturan terkait bangunan tahan gempa sudah mengalami pembaharuan yaitu SNI 1726:2019. Pada kajian ini penulis berusaha mengkaji konsekuensi dari perubahan peraturan terhadap perilaku bangunan CLT dengan membandingkan hasil analisa terhadap peraturan bangunan tahan gempa terbaru dengan peraturan sebelumnya yaitu SNI 1726:2012. Kajian ini dilakukan untuk mengetahui apakah CLT masih memberikan performa yang baik pada bangunan bertingkat menengah dengan 
ditinjau sebagai akibat dari perubahan beban gempa desain terbaru.

Kajian ini dilakukan dengan menggunakan model 3D pada software SAP2000. Lingkup dari kajian ini adalah analisa pemodelan struktur bangunan di atas tanah. Sedangkan, bagian struktur bawah yaitu fondasi, tidak dianalisa pada kajian ini. Disebabkan produk CLT belum berada di pasaran Indonesia, maka kajian ini menggunakan spesifikasi produk CLT yang umum di pasaran dunia dan diadaptasi pada peraturan mengenai CLT yang ada di negara lain serta parameter penyesuaian yang diambil dari kajian sebelumnya.

CLT tersusun dari minimum tiga lapisan plywood dengan arah serat kayu yang saling tegak lurus antar lapisannya. Pada panel dengan jumlah lapisan ganjil, maka terdapat sumbu kuat dan sumbu lemah. Sumbu kuat merupakan sumbu yang memiki lapisan dengan arah serat sejajar terbanyak, sedangkan sumbu lemah adalah sumbu yang memiliki lapisan tegak lurus dari sumbu kuat.

Penentuan arah sumbu ini sangat penting pada pemodelan maupun pemasangan panel di lapangan. Hal ini dikarenakan perilaku yang telah dimodelkan akan tercapai apabila pelaksaannya dilakukan dengan benar.

Pada suatu panel dengan bukaan, maka distribusi tegangan menjadi tidak merata dan rentan terjadi kegagalan pada daerah tersebut.

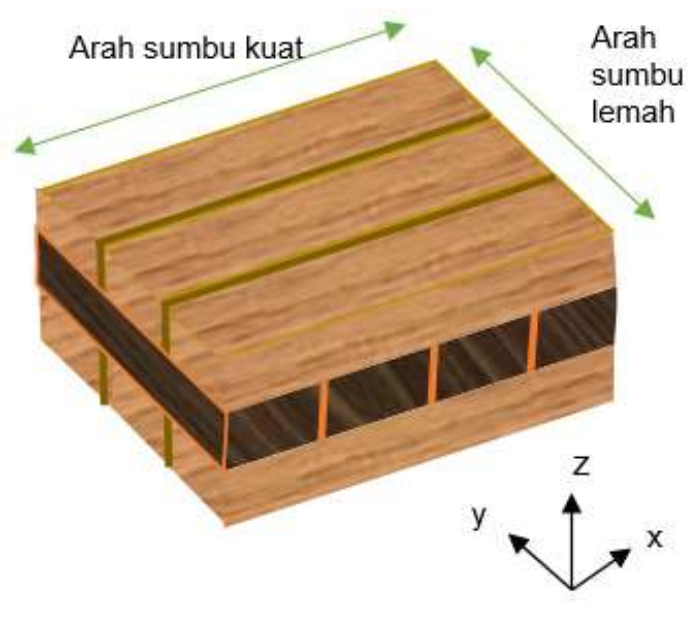

Gambar 1. Penampang CLT

Kayu merupakan material yang memiliki serat, sehingga apabila terjadi retak, maka kekuatannya akan berkurang jauh dan kerusakan dapat menjalar. Untuk mengantisipasi hal tersebut, maka dilakukan modifikasi pada pemodelan.

Gambar 1 menunjukkan suatu dinding yang memiliki bukaan pintu. Pintu merupakan akses yang umum ada pada suatu ruangan sehingga keberadaannya tidak bisa dieliminasi. Dalam mengantisipasi distribusi tegangan yang tidak merata dan retak geser yang menjalar, maka pada kajian ini area sekitar bukaan pintu, yang didesain sebagai kusen tidak diperhitungkan sebagai komponen struktural. Dengan kata lain, dinding CLT tidak menerus pada area yang memiliki bukaan pintu. 
Perbandingan Perilaku Bangunan... (lka/ hal 130-143)

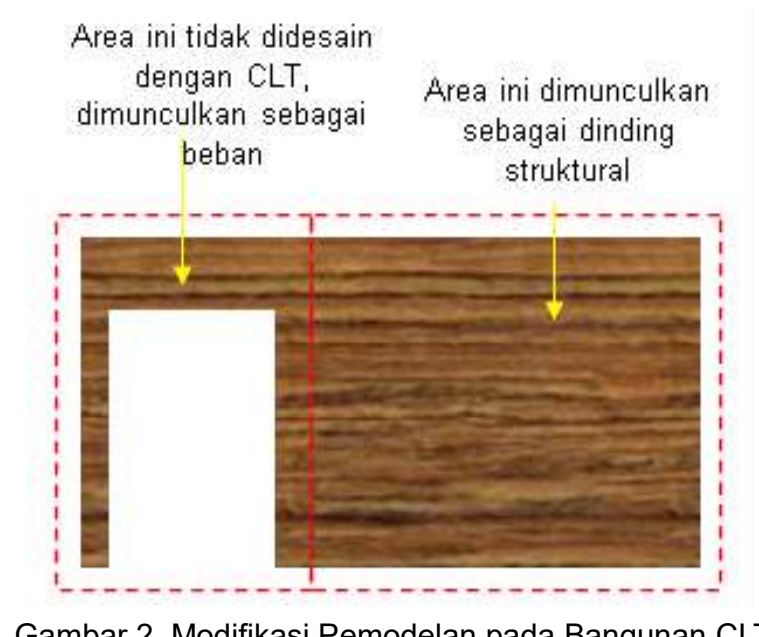

Selain itu, Dujic, 2006, menyatakan bahwa nilai tahanan dan kekakuan geser dari panel CLT berkurang dengan adanya bukaan.

Faktor reduksi untuk panel CLT dengan bukaan diambil sebesar 0,5

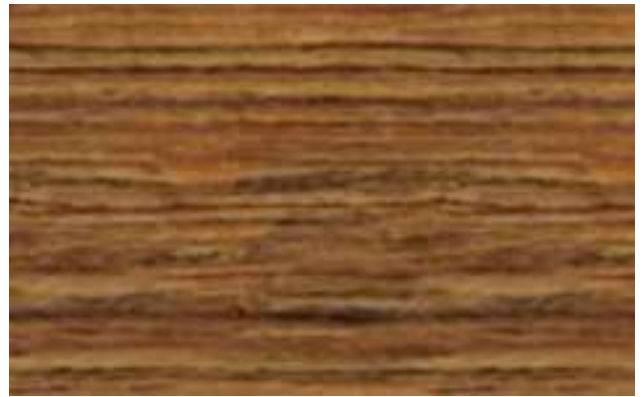

(a)

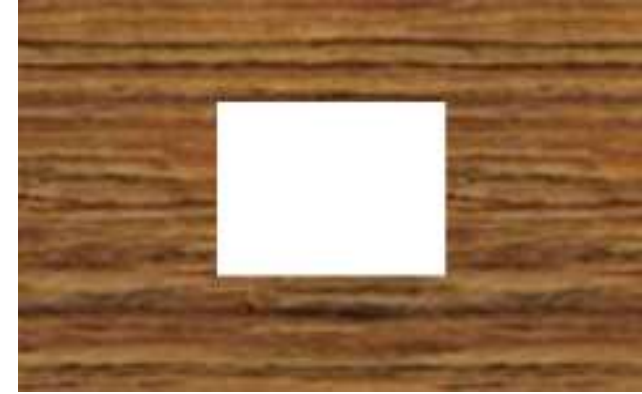

(b)

Gambar 3. Panel CLT (a) Tanpa Bukaan; (b) Dengan Bukaan

Desain bangunan tahan gempa memiliki batasan yang diatur dalam SNI 1726:2019 dan sebelumnya pada SNI 1726:2012. Dari kedua standar ini, nilai koefisien modifikasi respon, $R$, faktor kuat lebih sistem, $\Omega_{0}$, dan faktor amplifikasi defleski, $C_{d}$, tidak mengalami perubahan untuk bangunan dengan dinding rangka ringan. Faktor-faktor tersebut belum diatur secara khusus untuk bangunan CLT. Berdasarkan penelitian oleh Pei, et al [] diambil nilai $R=2$. Sedangkan untuk faktor amplifikasi defleksi dan faktor kuat lebih sistem diambil sebesar $C_{d}=2.5$, dan $\Omega_{0}=2$.
Nilai parameter respons percepatan gempa juga mengalami perubahan. Pada peta gempa yang dikeluarkan Puskim pada 2011, dikatakan parameter respons percepatan di area Yogyakarta untuk periode pendek, $S_{s}=1,212$, dan parameter respons percepatan untuk periode 1 detik, $S_{1}=0,444$. Sedangkan pada peta gempa Puskim yang dikeluarkan bersamaan dengan SNI 1726:2019 nilai $S_{s}$ adalah 0,788121 , dan nilai $S_{1}$ adalah sebesar 0,388649 . 


\section{METODE}

Kajian ini dilakukan dengan mengambil konfigurasi struktur pada suatu bangunan asrama di Yogyakarta. Bangunan ini merupakan gedung lima lantai dengan panjang total, $P=60 \mathrm{~m}$ dan lebar total, $L=$ 19,2 m. Tinggi tiap lantai bangunan ini adalah sama yaitu 2,8 $\mathrm{m}$. Denah bangunan merupakan bangunan dengan denah tipikal tiap lantainya karena merupakan bangunan residensial. Atap bangunan ini disesuaikan menjadi panel CLT. Adapun tahapan kajian dapat dilihat pada Gambar 4.

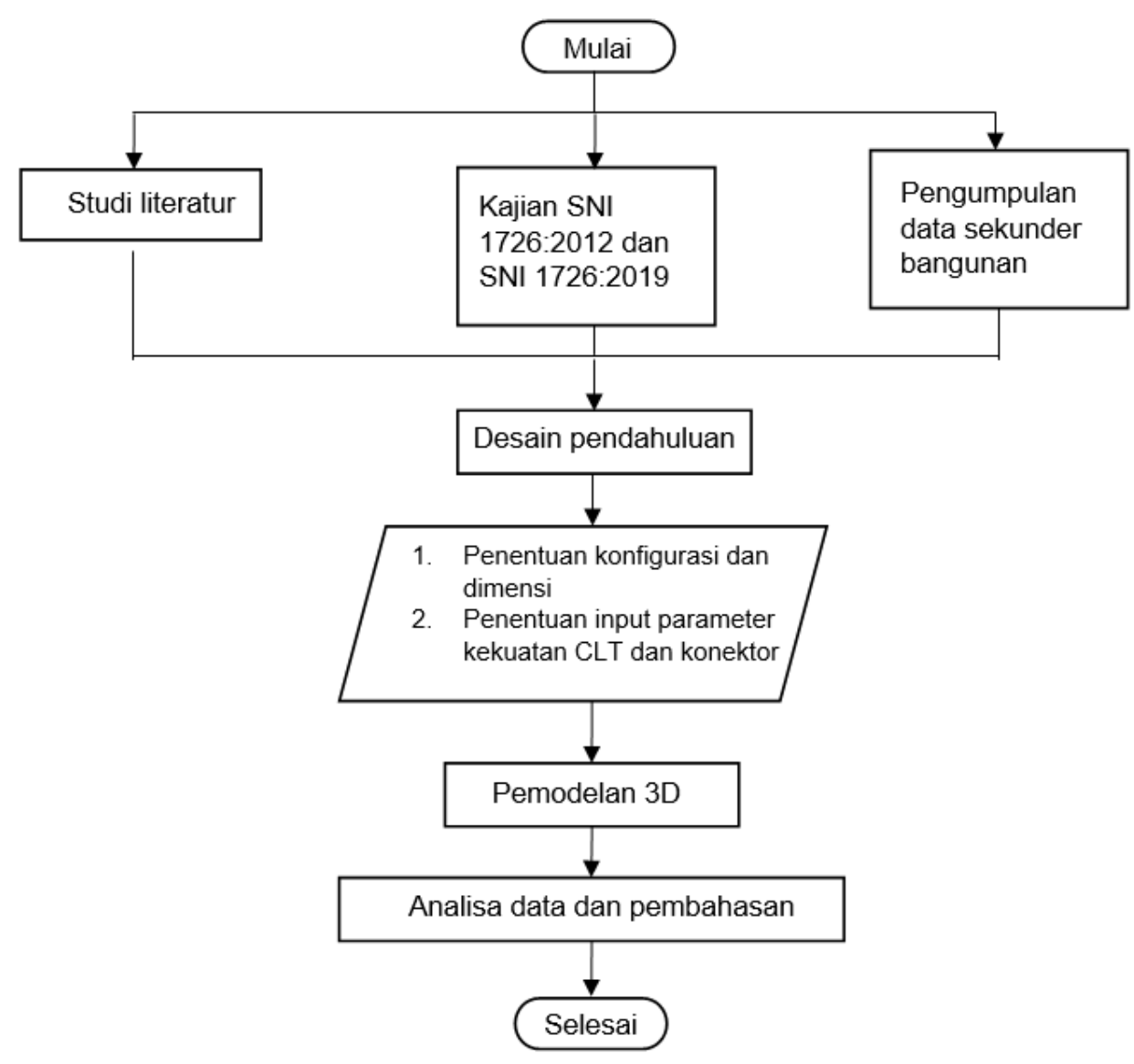

Gambar 4. Bagan Alur Pelaksanaan Kajian

Pada kajian ini digunakan mutu CLT berupa E1 yang sudah umum dipakai dalam konstruksi gedung di luar negeri seperti di Kanada. Spesifikasi kekuatan lapisan panel CLT pada arah sumbu kuat dan sumbu lemah dapat dilihat pada Tabel 1 []. Kekuatan ini menjadi nilai dasar yang digunakan untuk pendekatan dalam

Tabel 1. Kekuatan Lapisan CLT Grade E1.

\begin{tabular}{llllllll}
\hline & $\boldsymbol{f}_{\boldsymbol{b}, \boldsymbol{0}}$ & $\boldsymbol{E}_{\boldsymbol{o}}$ & $\boldsymbol{\boldsymbol { f } _ { \boldsymbol { t } , \boldsymbol { 0 } }}$ & $\boldsymbol{f}_{\boldsymbol{c}, \boldsymbol{0}}$ & $\boldsymbol{f}_{\boldsymbol{v}, \boldsymbol{0}}$ & $\boldsymbol{f}_{\boldsymbol{s}, \boldsymbol{0}}$ & $\mathbf{G}_{\boldsymbol{o}}$ \\
& $\mathrm{MPa}$ & $\mathrm{MPa}$ & $\mathrm{MPa}$ & $\mathrm{MPa}$ & $\mathrm{MPa}$ & $\mathrm{MPa}$ & $\mathrm{MPa}$ \\
\hline Arah sumbu kuat & 28,3 & 11722 & 19,9 & 23,6 & 2,9 & 0,97 & 732,6 \\
Arah sumbu lemah & 7,2 & 8274 & 3,6 & 8,5 & 2,9 & 0,96 & 517,1 \\
\hline
\end{tabular}


Perbandingan Perilaku Bangunan... (Ika/ hal 130-143)

Keterangan dari simbol $f_{b, 0}, f_{t, 0}, f_{c, 0}, f_{v, 0}, f_{s, 0}$ berturut-turut adalah tahanan terhadap tekuk, tarik, tekan, geser tegak lurus serat dan geser sejajar serat pada satu lapisan. Sedangkan $E_{0}$ adalah modulus elastisitas pada satu lapisan dan $G_{0}$ adalah modulus geser pada satu lapisan. Tahanan panel CLT akan bergantung pada tebal lapisan dan jumlah lapisan.
Pada kajian ini digunakan panel CLT yang tersusun dari lima lapis plywood. Masingmasing lapisan memiliki tebal yang seragam yaitu $38 \mathrm{~mm}$ seperti yang dapat dilihat pada Gambar 5.

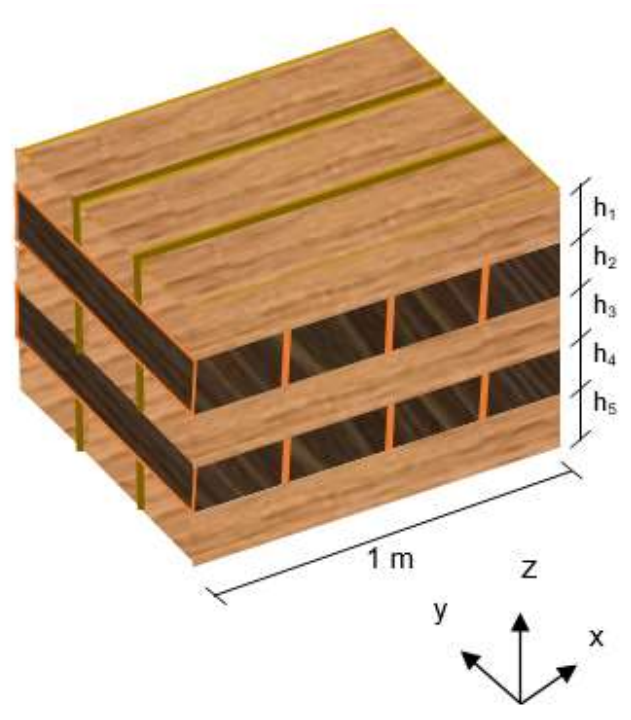

Gambar 5. Panel CLT per m Panjang

Sebagai input pada SAP2000, kekuatan panel CLT perlu dihitung per $\mathrm{m}$ panjang. Adapun nilai modulus elastisitas efektif, $(E)_{\text {eff, }}$ dapat diperoleh menggunakan persamaan berikut:

$(E I)_{\text {eff }}=\sum_{i=1}^{n} E_{i} b_{i} \frac{h_{i}^{2}}{12}+\sum_{i=1}^{n} E_{i} A_{i} z_{i}^{2}$

keterangan:

$b_{i}=$ lebar panel

$h_{i}=$ tebal lapisan ke- $i$

$A_{i}=$ luas area lapisan per $\mathrm{m}$ panjang

$z_{l}=$ jarak dari titik pusat penampang panel ke lapisan- $i$

Sedangkan $E i$ adalah nilai modulus elastisitas lapisan yang didapatkan dari Tabel 1 sesuai dengan arah sumbu yang ditetapkan.
Nilai modulus geser efektif, $(G A)_{\text {eff, }}$ panel CLT yang terdiri dari lima lapis plywood dengan tebal total $190 \mathrm{~mm}$ dapat dihitung dengan persamaan berikut:

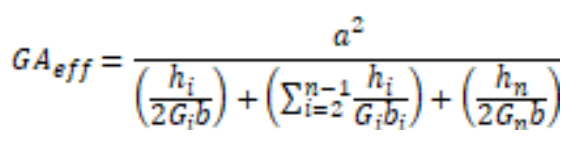

keterangan:

$\mathrm{a}=$ jarak antar titik pusat lapisan terluar

$h_{i}=$ tebal lapisan pada suatu panel CLT yang berada di bagian atas dari lapisan tengah ( $h_{1}$ dan $h_{2}$ pada Gambar 5$)$

$G_{i}=$ modulus geser lapisan pada lapisan 1 dan 2 Gambar 5

$h_{n}=$ tebal lapisan pada suatu panel CLT yang berada di bagian bawah dari lapisan tengah ( $h_{4}$ dan $h_{5}$ pada Gambar 5) 
$G_{n}=$ modulus geser lapisan yang tergantung pada lapisan 4 dan 5 pada Gambar 5
Kekuatan panel berdasarkan modulus elastisitas dan geser efektif dapat dilihat pada Tabel 2.

Tabel 2. Kekuatan Panel CLT.

\begin{tabular}{ccc}
\hline & Sumbu lokal panel & $\mathrm{Y}$ \\
& $\mathrm{X}$ & $\left(\mathrm{N} \mathrm{mm}^{2}\right)$ \\
\hline$(E l)_{\text {eff }}$ & $\left(\mathrm{N} \mathrm{mm}^{2}\right)$ & $1,16 \mathrm{E}+12$ \\
$(G A)_{\text {eff }}$ & $5,34 \mathrm{E}+12$ & $1,95 \mathrm{E}+07$ \\
\hline
\end{tabular}

Yasumura, 2015, mengusulkan sebuah pendekatan untuk menghitung nilai kekuatan panel pada arah sebidang (inplane) dan tegak lurus bidang (out-ofplane). Modulus elastisitas out-of-plane didapatkan dengan membagi nilai modulus elastisitas efektif, (EI)eff, dengan momen inersia pada arah sumbu kuat dan sumbu lemahnya $\left(I_{x}\right.$ atau $\left.I_{y}\right)$.

Sementara nilai modulus elastisitas in-plane didapatkan dengan membagi total nilai modulus elastisitas sesuai arah serat lapisannya yang didapatkan dari Tabel 1 dengan jumlah lapisannya. Berdasarkan
SNI 7973:2013 nilai modulus geser in-plane didapatkan dengan membagi total nilai modulus geser dengan 16 .

Dari hasil hitungan tersebut didapatkan nilai modulus elastisitas seperti yang tertera pada Tabel 3. Sedangkan untuk nilai modulus geser dapat dilihat pada Tabel 4

Kendati merupakan bangunan simetris, bangunan dimodelkan secara tiga dimensi dengan mempertimbangkan integritas struktur pada semua arah. Selain itu hal ini juga untuk mengalisa pengaruh gempa minor pada arah gempa major.

Tabel 3. Nilai dan Notasi Modulus Elastisitas CLT.

\begin{tabular}{ccc}
\hline & Modulus elastisitas per m panjang \\
\hline Input SAP2000 & Notasi sumbu lokal & Nilai \\
& & MPa \\
\hline$E_{12}$ & $E_{r x}$ & 9340 \\
$E_{13}$ & $E_{r y}$ & 2030 \\
$E_{23}$ & $\left(E_{x}+E_{y}\right) / 2$ & 5171 \\
\hline
\end{tabular}

Tabel 4. Nilai dan Notasi Modulus Geser CLT.

\begin{tabular}{ccc}
\hline & Modulus geser per m panjang \\
\hline Input SAP2000 & Notasi sumbu lokal & Nilai \\
& & MPa \\
\hline$G_{12}$ & $G_{x y}$ & 440 \\
$G_{13}$ & $G_{z x}$ & 103 \\
$G_{23}$ & $G_{y z}$ & 78 \\
\hline
\end{tabular}

Sambungan pada CLT menggunakan bracket siku BMF dan HBS screw. Pada kajian ini digunakan enam buah screw pada tiap pelat $B M F$ dengan kekuatan yang berbeda. Tipe sambungan dibedakan berdasarkan jenis panel yang disambung yaitu dinding-ke-lantai, dinding-ke-dinding, dan dinding-ke-beton (pada lantai kerja di dasar bangunan). Ilustrasi tipe sambungan lantai-ke-dinding beserta pemodelannya dapat dilihat pada Gambar 6. Adapun kekuatan sambungan tersebut dapat dilihat pada Tabel 5.

Sambungan yang menyambungkan dinding-ke-dinding tegak lurus dapat dilihat pada Gambar 7 dan spesifikasi sambungan 
Perbandingan Perilaku Bangunan... (Ika/ hal 130-143)

beserta notasi input SAP2000 dapat dilihat Tabel 6. Sedangkan untuk sambungan antara panel CLT dengan lantai kerja beton dapat dilihat pada Gambar 8. Spesifikasi sambungan ini disajikan pada Tabel 7. Sambungan untuk panel menerus tidak dimodelkan dalam SAP2000.

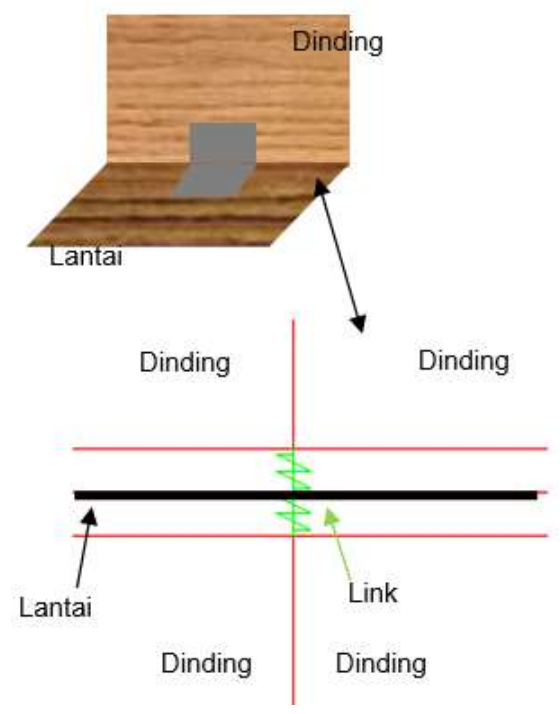

Gambar 6. Sambungan Lantai ke Dinding

Tabel 5. Notasi dan Input Kekuatan Link Dinding-ke-Dinding Tegak Lurus.

\begin{tabular}{ccc}
\hline SAP2000 & Shahnewaz & Nilai \\
\hline Stiffness U1 & $k_{e l .3}$ & $2,90 \mathrm{kN} / \mathrm{mm}$ \\
Stiffness U2 & $k_{e l .2}$ & $1,49 \mathrm{kN} / \mathrm{mm}$ \\
Stiffness U3 & $k_{e l .1}$ & $1,30 \mathrm{kN} / \mathrm{mm}$ \\
Damping coefficient U1 & $u_{3}$ & $12,66 \%$ \\
Damping coefficient U2 & $u_{2}$ & $1,15 \%$ \\
Damping coefficient U3 & $u_{1}$ & $10,41 \%$ \\
\hline
\end{tabular}

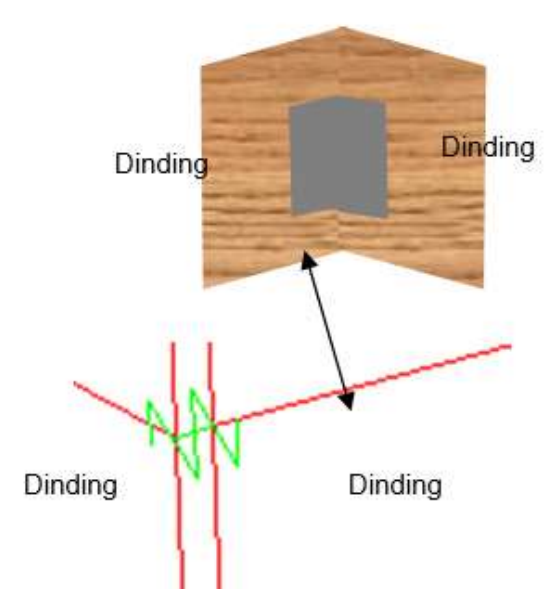

Gambar 7. Sambungan Dinding-dinding yang Tegak Lurus

Tabel 6. Notasi dan Input Kekuatan Link Dinding-ke-Dinding Tegak Lurus.

\begin{tabular}{ccc}
\hline SAP2000 & Shahnewaz & Nilai \\
\hline Stiffness U1 & $k_{e l .3}$ & $2,90 \mathrm{kN} / \mathrm{mm}$ \\
Stiffness U2 & $k_{e l .2}$ & $1,49 \mathrm{kN} / \mathrm{mm}$ \\
Stiffness U3 & $k_{e l .1}$ & $1,30 \mathrm{kN} / \mathrm{mm}$ \\
Damping coefficient U1 & $u_{3}$ & $12,66 \%$ \\
Damping coefficient U2 & $u_{2}$ & $1,15 \%$ \\
Damping coefficient U3 & $u_{1}$ & $10,41 \%$ \\
\hline
\end{tabular}


Agar dapat melakukan assign sambungan pada model, maka panel pelat dan dinding dibagi ke dalam dimensi yang lebih kecil yaitu $0,5 \mathrm{~m} \times 0,5 \mathrm{~m}$. Pemodelan sambungan juga mempertimbangkan batasan-batasan ruang di lapangan seperti tidak memasang sambungan pada ujung-ujung dinding sebab pemasangan sambungan tidak mungkin dilakukan pada sambungan tipe BMF dan HBS screw. Pada dasarnya, demi tercapainya kemudahan pengerjaan di lapangan, maka panel di modelkan dengan sambungan kaku sehingga dapat diasumsikan sebagai panel menerus. Pada panel dinding yang menerus, apabila dikehendaki maka dapat digunakan sambungan dengan dowel yang berupa pelat yang diisikan pada bagian tengah pada panel menerus sedangkan panel tegak lurus dipasang menggunakan bracket.

Tabel 7. Notasi dan Input Kekuatan Link CLT dan Beton.

\begin{tabular}{ccc}
\hline SAP2000 & Shahnewaz & Nilai \\
\hline Stiffness U1 & $k_{e l .3}$ & $2,09 \mathrm{kN} / \mathrm{mm}$ \\
Stiffness U2 & $k_{\text {el. }}$ & $2,53 \mathrm{kN} / \mathrm{mm}$ \\
Stiffness U3 & $k_{e l .1}$ & Rigid \\
\hline
\end{tabular}

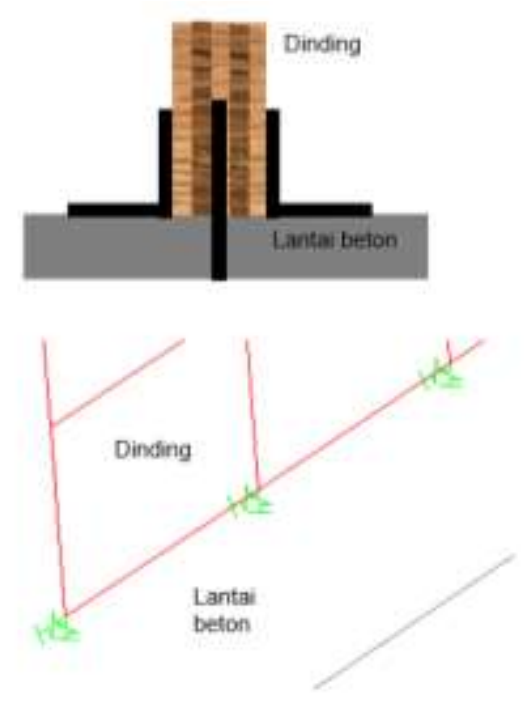

Gambar 8. Sambungan Antara Panel CLT dan Lantai Kerja Beton

Pelat lantai menerus dianggap kaku, atau paku sehingga sambungan tipe kaku sebagai pendekatan, dengan tercapai. Pada SAP2000, pelat di assign mengasumsikan bahwa antar pelat dengan constraint berupa diafragma kaku disambung menggunakan dowel dan baut pada setiap lantai. 
Perbandingan Perilaku Bangunan... (Ika/ hal 130-143)

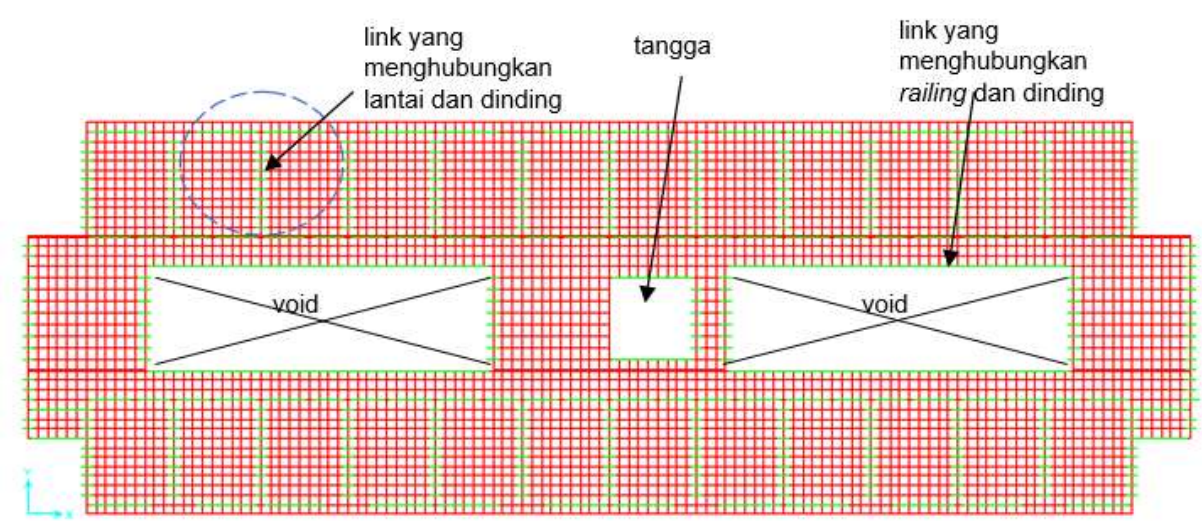

Gambar 9. Denah Struktur Lantai Tipikal

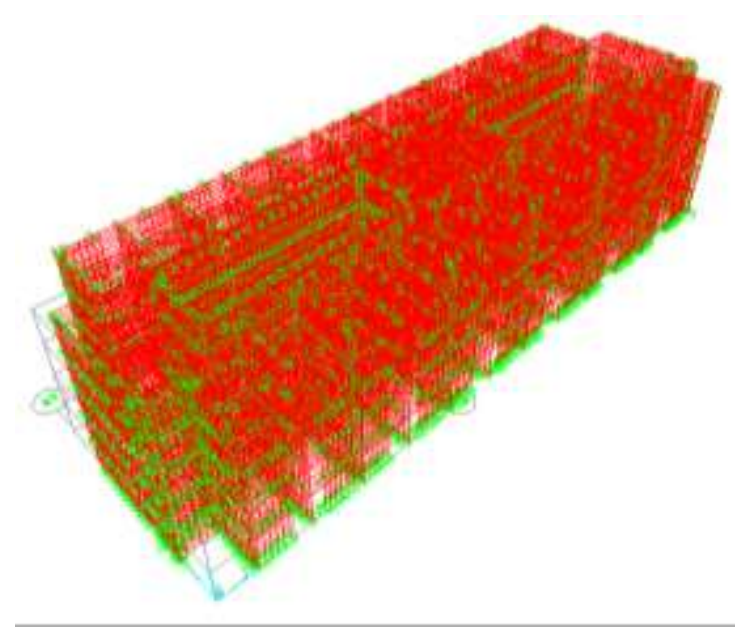

Gambar 10. Pemodelan 3D SAP2000 dengan Shell dan Link

\section{HASIL DAN PEMBAHASAN}

Pada SNI 1726:2012, koefisien untuk percepatan dasar didapatkan pada peta gempa yang dikeluarkan oleh Puskim pada tahun 2011. Lokasi pengambilan nilai koefisien pada studi kasus untuk kajian ini adalah di kabupaten Sleman.
Dari hasil analisa terhadap parameter percepatan respon spektra MCE dengan redaman $5 \%$ pada periode pendek, $S_{S}$, dan pada periode 1 detik, $S_{1}$, didapatkan output nilai $S_{D S}, S_{D 1}, T_{0}$, dan $T_{1}$ seperti yang dapat dilihat pada Tabel 10.

Tabel 10. Perbandingan Parameter Gempa.

\begin{tabular}{lll}
\hline & SNI 1726:2012 & SNI 1726:2019 \\
\hline$S_{D S}$ & 0,820 & 0,614 \\
$S_{M S}$ & 0,461 & 0,495 \\
$T_{0}$ & 0,112 & 0,161 \\
$T_{1}$ & 0,561 & 0,806 \\
\hline
\end{tabular}

Dari hasil tersebut didapatkan grafik respon skpektra yang dapat dilihat pada Gambar 11. Nilai respon spektra dengan parameter gempa Puskim 2011 lebih tinggi dari nilai respon spektra hasil analisa parameter gempa Puskim 2019. 


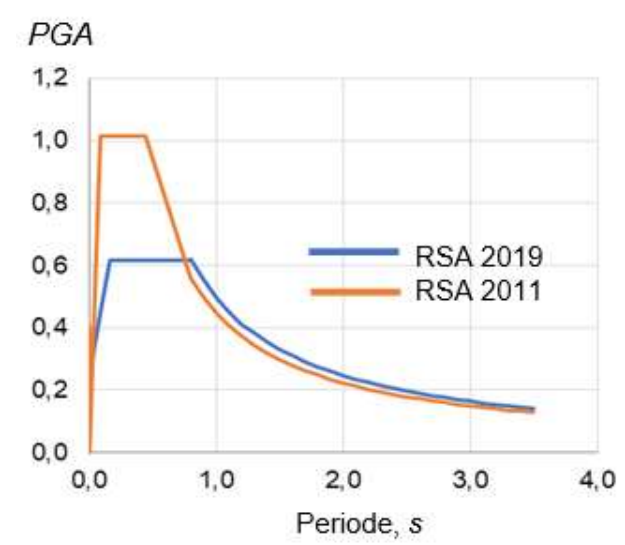

Gambar 11. Grafik Respons Spektrum Percepatan untuk Peta Gempa 2011 dan Peta Gempa 2019

Gaya gempa yang dianalisa menggunakan SNI 1726:2012 mengizinkan gaya geser untuk direduksi menjadi $85 \%$ sedangkan pada SNI 1726:2019 digunakan gaya gempa secara penuh.

Gambar 12 menunjukan grafik perbandingan simpangan arah $\mathrm{x}$ hasil analisa pemodelan 3D dengan SAP2000.
Dari gambar tersebut didapati bahwa simpangan akibat beban gempa berdasarkan SNI 1726:2019 cenderung lebih kecil bila dibandingkan dengan simpangan akibat peraturan gempa sebelumnya. Kendati nilai simpangannya berbeda, grafik menunjukkan bahwa bentuk kurva deformasi dari bangunan juga tidak jauh berbeda.

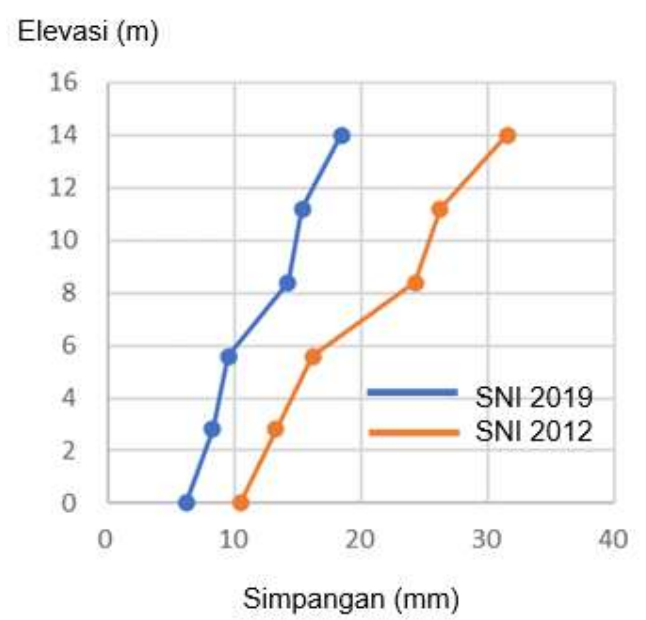

Gambar 12. Simpangan Arah X Pada Tiap Elevasi

Tabel 11. Simpangan Antar Lantai Kumulatif Terhadap Persyaratan SNI.

\begin{tabular}{ccccccccc}
\hline & \multicolumn{4}{c}{ SNI 1726:2012 } & \multicolumn{4}{c}{ SNI 1726:2019 } \\
\cline { 2 - 9 } Lantai & \multicolumn{3}{c}{ Simpangan arah $\mathrm{x}$} & \multicolumn{2}{c}{ Simpangan arah y } & \multicolumn{2}{c}{ Simpangan arah $\mathrm{x}$} & \multicolumn{3}{c}{ Simpangan arah y } \\
\cline { 2 - 10 } & $\begin{array}{c}\text { Output } \\
\mathrm{mm}\end{array}$ & $\begin{array}{c}\text { Batas } \\
\mathrm{mm}\end{array}$ & $\begin{array}{c}\text { Output } \\
\mathrm{mm}\end{array}$ & $\begin{array}{c}\text { Batas } \\
\mathrm{mm}\end{array}$ & $\begin{array}{c}\text { Output } \\
\mathrm{mm}\end{array}$ & $\begin{array}{c}\text { Batas } \\
\mathrm{mm}\end{array}$ & $\begin{array}{c}\text { Output } \\
\mathrm{mm}\end{array}$ & $\begin{array}{c}\text { Batas } \\
\mathrm{mm}\end{array}$ \\
\hline 5 & 42,01 & 280 & 25,63 & 280 & 24,49 & 280 & 15,35 & 280 \\
4 & 31,46 & 224 & 20,84 & 224 & 18,36 & 224 & 12,50 & 224 \\
3 & 27,51 & 168 & 15,99 & 168 & 16,11 & 168 & 9,63 & 168 \\
2 & 11,39 & 112 & 8,35 & 112 & 6,65 & 112 & 5,03 & 112 \\
1 & 5,55 & 56 & 4,31 & 56 & 4,15 & 56 & 2,63 & 56 \\
\hline
\end{tabular}


Perbandingan Perilaku Bangunan... (Ika/ hal 130-143)

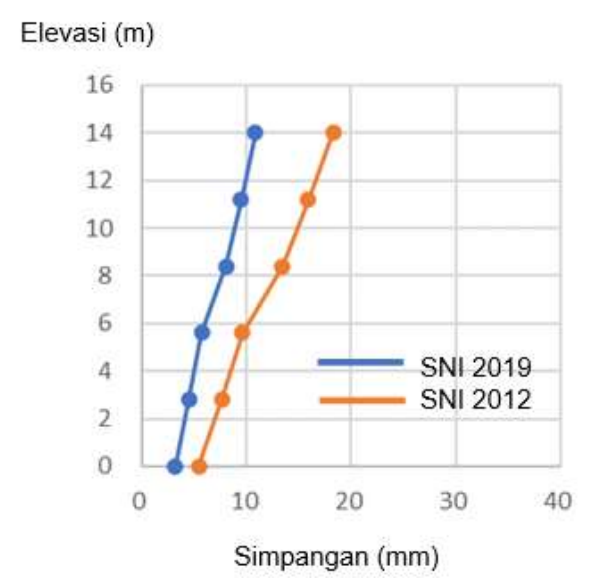

Gambar 13. Simpangan Arah Y Pada Tiap Elevasi

Simpangan pada arah y disajikan pada Gambar 13. Seperti halnya pada arah $\mathrm{x}$, didapatkan bahwa simpangan akibat peraturan gempa terbaru lebih kecil daripada peraturan gempa yang berlaku sebelumnya. Meskipun demikian, terdapat kesamaan pada bentuk kurva deformasi.

Dari Tabel 11 didapatkan nilai simpangan kumulatif yang sudah dikalikan dengan faktor pembesaran, $C_{d}$. Hasil tersebut disandingkan dengan persyaratan atau batas yang diizinkan dalam SNI 1726:2012 dan SNI 1726:2019. Hasil analisa menunjukkan nilai simpangan antar lantai masih memenuhi kedua persyaratan.
Selain itu, dapat diamati perbandingan simpangan antar lantai yang terjadi pada arah X seperti yang dapat dilihat pada Gambar 14. Seperti sebelumnya, hasil analisa dengan gempa terbaru menunjukan hasil yang cenderung lebih kecil dibandingkan hasil analisa menggunakan peraturan gempa sebelumnya. Hal ini juga berlaku pada simpangan antar lantai arah $\mathrm{Y}$ yang dapat dilihat pada Gambar 15.

Konsekuensi dari perubahan peraturan desain juga berpengaruh terhadap gaya geser akibat beban lateral pada diafragma. Distribusi gaya lateral pada diafragma dapat dilihat pada Tabel 12.

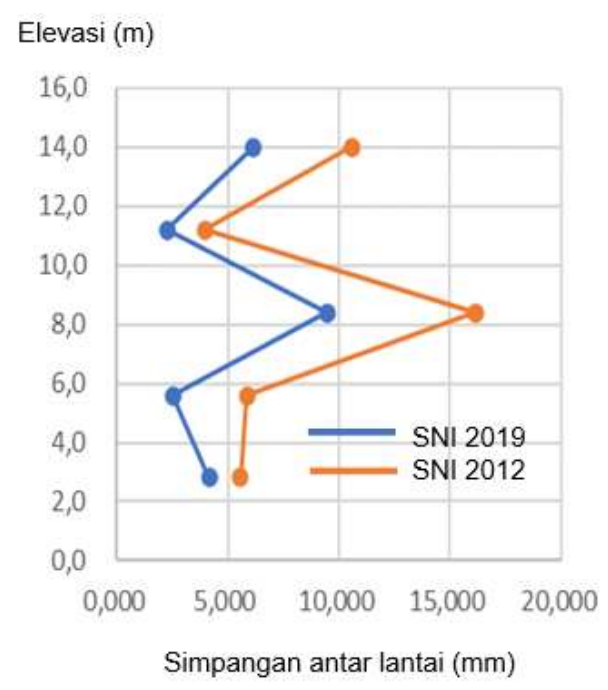

Gambar 14. Simpangan Antar Lantai Arah X 


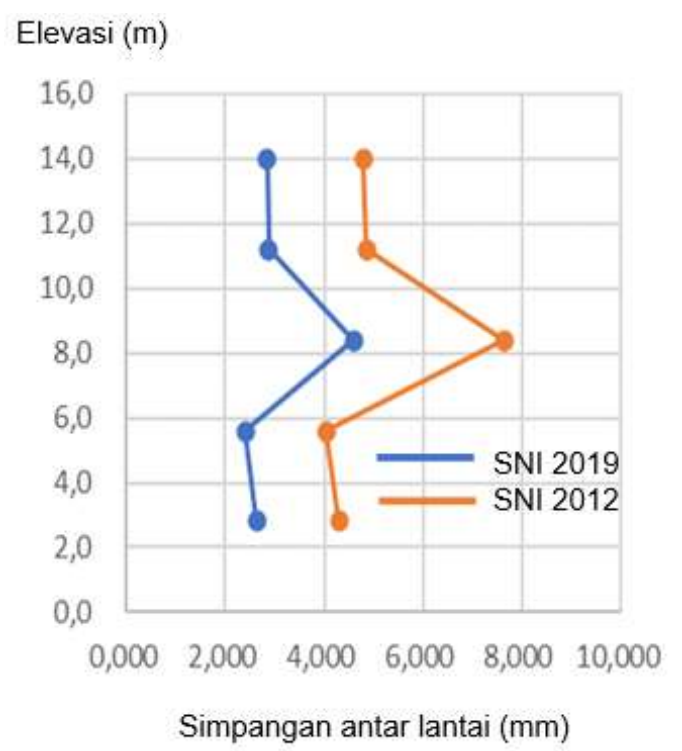

Gambar 15. Simpangan Antar Lantai Arah Y

Tabel 12. Gaya Lateral pada Diafragma.

\begin{tabular}{ccc}
\hline Lantai ke- & 2012 & 2019 \\
& $\mathrm{kN}$ & $\mathrm{kN}$ \\
\hline 5 & 1120 & 658 \\
4 & 1433 & 842 \\
3 & 806 & 474 \\
2 & 358 & 210 \\
1 & 89 & 53 \\
\hline
\end{tabular}

Dari hasil analisa terhadap gaya desain diafragma maka dapat dicari jumlah kebutuhan konektor pada masing-masing lantai yang dapat dilihat pada Tabel 13 . Kebutuhan konektor ini digunakan pada konektor lantai-ke-dinding.

Tabel 13. Jumlah Konektor Lantai-ke-Dinding.

\begin{tabular}{ccc}
\hline Lantai ke- & 2012 & 2019 \\
& $\mathrm{kN}$ & $\mathrm{kN}$ \\
\hline 5 & 68 & 40 \\
4 & 154 & 92 \\
3 & 204 & 120 \\
2 & 224 & 132 \\
1 & 230 & 136 \\
\hline
\end{tabular}

\section{SIMPULAN}

Setelah dilakukan studi mengenai perbandingan perilaku bangunan CLT berdasarkan SNI 1726:2012 dan SNI1726:2019 didapatkan hasil bahwa kedua model masih memenuhi persyaratan simpangan yang ditentukan pada masing-masing peraturan. Pemodelan dilakukan untuk mensimulasikan gedung lima lantai dengan material utama berupa panel-panel CLT tanpa rangka. Pemodelan 3D dieksekusi menggunakan software SAP2000 menunjukkan bahwa bangunan dengan CLT menghasilkan berat struktur yang lebih ringan dibandingkan dengan beton. Hal ini mengindikasikan bahwa CLT dapat digunakan sebagai material utama pada bangunan bertingkat menengah yang mampu menahan beban lateral berdasarkan gempa terbaru. 


\section{DAFTAR RUJUKAN}

Brandner, R., et al, (2016). Cross laminated timber (CLT): overview and development, European Journal of Wood and Wood Products, v. 74, n. 3, pp 331-351.

Dujic, B. (2006). Shear capacity of CrossLaminated Wooden Walls. Doctoral dissertation: University of Llubjlana, Slovenia.

Gavric, I.; Fragiacomo, M.; Ceccotti, A. (2015). Cyclic Behaviour of CLT Wall Systems: Experimental Tests and Analytical Prediction Model. J. Struct. Eng.

Hermawan, Marzuki, P.F, Abduh, M., Drierjana, R. (2015). Identification of source factors of carbon dioxide (CO2) emissions in concreting of reinforced concrete, Procedia Engineering, v.125 pp 692-698.

Okabe, M., Yasumura, M. Kobayashi, K., Fujita, K. (2013) Prediction of bending stiffness and moment carrying capacity of sugi cross-laminated timber. Journal of Wood Science, 60(1).

Pei, S., Lindt, J. W., \& Popovski, M. (2013). Approximate R-Factor for CrossLaminated Timber Walls in Multisroty Buildings. Journal of Architectural Engineering, ASCE, 19(4), 245-255.

Pratama, G. N. I. P. P., \& Najihan, H. F. (2020, September). The Effect of Beach Sands to Replacement of Fine Aggregate with Addition Filler of Ash Cane on the Asphalt Mixture on Marshall Characteristics. In Journal of Physics: Conference Series (Vol. 1625, No. 1, p. 012032). IOP Publishing.

Shahnewaz, Md. Alam, S., Tanner, T. (2018). Inplane strength and stiffness of cross- laminated timber shear walls. Journal Buildings, 8.

SNI 1726:2012 Tata cara perencanaan ketahanan gempa untuk struktur bangunan gedung dan non-gedung.

SNI 1726:2019 Tata cara perencanaan ketahanan gempa untuk struktur bangunan gedung dan non-gedung.

SNI 1727:2013 Beban minimum untuk perancangan bangunan gedung dan struktur lain.

United Nations, Department of Economic and Social Affairs, Population Division. (2018). The Worlds' Cities in 2018-Data Booklet. (ST/ESA/SER.A/417).

United Nations, (2015). Transforming our world: The 2030 Agenda for Sustainable Development. (A/RES/70/1).

Yasumura, M., Kenji, K., Okabe, M., Miyake, T., \& Matsumoto, K. (2015). Full scale tests and numerical analysis of Low-Rise CLT Structures under Lateral Loading. J. Struct. Eng 142 (4). 